\title{
巨大地震津波による東京都心部の 中小河川の汇濫予測 \\ ESTIMATION OF INUNDATION AREA IN CENTRAL TOKYO DUE TO ASCENDING TSUNAMI ALONG RIVER GENERATE BY MEGA EARTHQUAK
}

\author{
高崎忠勝 1 ・土屋十图 2 \\ Tadakatsu TAKASAKI and Mitsukuni TSUTIYA \\ 1正会員 博(工) 東京都土木技術支援・人材育成センター（テ136-0075 東京都江東区新砂一丁目9-15） \\ 2フェロー会員 工博 中央大学理工学研究所（干112-8551 東京都文京区春日1-13-27）
}

\begin{abstract}
It is estimated that maximum sea water level became $3 \mathrm{~m}$ at area of Tokyo bay based on the earthquake tsunami that report II of committee on the Mega earthquake model of the Nankai Troughs. Therefore, we carried out an analysis of ascending tsunami at a small river in the central Tokyo. We had investigated by unsteady flow of $1 \mathrm{D}$ analysis, still more, using an observation data that changing of river water level in the east Japan great earthquake. Further more, we analysis under condition of an estimated tsunami of $3 \mathrm{~m}$, and two case of water gates open and close. The result is following, if water gate could not close in the Kamejima river, inundation area was simulated at around of river area due to flow in tsunami , maximum inundation water depth and area became $4.8 \mathrm{~m}, 0.65 \mathrm{~km}^{2}$. It was found that the most important mater is management of water gates when Mega earthquake occur.
\end{abstract}

Key Words : Capital area, maximum tsunami water level, management of water gates, inundation area, Mega earth quake

\section{1.はじめに}

2011年3月11日の東北地方太平洋沖地震（以下，本地 震) では，東北地方から関東地方の広範囲にわたって直 轄区間および都道府県管理区間において堤防の被災や水 門閉鎖や遠隔操作に支障を生じた事例がみられた $。$ 東 京の東部低地帯には高潮対策として多くの水門や排水機 場が設置されている.これらの施設は本地震に対しては 被災しなかったものの, 今後発生する巨大地震において は機能の損失が危惧される.

地震による被災に加えて本地震に伴う津波（以下，本 津波）によって東北地方や関東地方の太平洋側を中心に 破堤等の被害が生じている22. 本津波による河川水位の 上昇は，東京を流れる河川においても確認され，例えば， 荒川下流域では0.8mの水位偏差が報告されている3).

本地震以降, 巨大地震に伴い発生する津波について再 検討が行われている．2012年4月18日に公表された首都 直下地震等による東京の被害想定4)では，地殻変動を考 慮した場合に中央区晴海で $2.41 \mathrm{~m}$ 最大津波高が生じる ことが示された5). 南海トラフの巨大地震モデル検討会 では，東京都区部の最大津波高として2012年3月31日の 第一次報告5)で2.3m，2012年8月29日の第二次報告6)にお いては $3 \mathrm{~m}$ であることを示している．東京の中小河川に おいても満潮時と巨大地震に伴う津波が重なることで極 めて大きな水位が生じる可能性がある.

都心部では地下空間が高度利用され，かつ，多くの資 産や昼間人口が集中しているため, 津波氾監が生じた場 合，甚大な被害を生じる可能性がある. このため, 都心 部を流れる多くの中小河川について地震津波に対する影 響を十分に検討する必要があると考える.

本研究では，津波に対する中小河川の影響検討の一事 例として，今後発生が想定される巨大地震に伴う津波

（以下，想定津波）に対する中小河川の影響検討の一事 例として，都心部を流れる中小河川について検討を行う。 具体的には，神田川の下流域および日本橋川，亀島川に ついて本津波時に下流で観測された水位を入力值とする 一次元不定流計算を行い, 本津波に対する水位変化の再 現性を検証する. 次に，想定津波の外力を設定し，この 外力に対する河川水位の変化を計算する. なお, これら の計算においては亀島川の上下流端に設置されている水 門の状態を開放と閉鎖の両方について行う。また，水理 計算において水位が堤防を超えた区間の周辺を対象に氾 濫計算を行い，浸水深および浸水範囲を確認する. 


\section{2. 対象範囲}

検討対象としたのは図-1に示寸ように神田川の下流域 および日本橋川，亀島川である．神田川はJR水道橋駅付 近で日本橋川と分派し，東方向に流下し，JR浅草橋駅付 近で隅田川に注ぐ一級河川である。 日本橋川は神田川か ら分派後, 南東方向に流下し, 日本橋水門地点で亀島川 と分派し隅田川に注ぐ延長4.8kmの河川である．亀島川 は日本橋川から分派後, 南方向に流れ隅田川に注ぐ延長 $1.1 \mathrm{~km}$ の河川であり，上下流端にはそれぞれ日本橋水門 と亀島川水門がある.これらの水門は高潮時に閉鎖され， 本津波に対してもこれらの水門は閉鎖された. 上下流端 に水門がある亀島川の堤防天端は，隅田川や日本橋川よ り低いものとなっている. これらの河川の他に水理計算 区間には上流から江戸橋分水路，水道橋分水路，お茶の 水分水路がある.

\section{3. 本津波による水位偏差}

\section{(1) 再現計算}

本津波による対象河川の水位変化について，MIKE11 （デンマーク水理・環境研究所）を用いて一次元不定流 計算により再現計算を行い，対象区間の水理特性を確認 する. 水理計算の対象区間は図-1に示したように神田川 下流域の $8 \mathrm{~km}$ おび日本橋川と亀島川の全延長である. 亀島川にある2つの水門は本津波到達前に閉鎖されてい るが，本計算では2つの水門が開いている状態と閉鎖し ている状態のそれぞれを対象とした．計算に用いた河川 断面は, 神田川が62断面, 日本橋川が43断面, 亀島川が 12断面の計117断面であり，他に江戸橋分水路，水道橋 分水路, お茶の水分水路についても断面を入力した. 粗 度係数は河川計画および流量観測結果》をもとに護岸コ ンクリート部を 0.0225 と, 護岸矢板部および河床部を

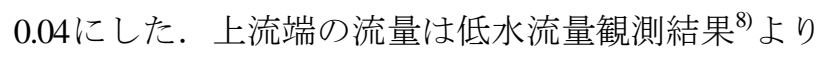
$4 \mathrm{~m}^{3} / \mathrm{s}$ と, 神田川, 日本橋川, 亀島川の各河川の下流 端水位は隅田川の清澄排水機場水位の観測值とした. 計 算間隔は0.1秒とし2011年3月9日から14日までを計算期 間とした。

本地震当日3月11日における4地点の水位および下流端 水位を図-2に示す。一休橋地点と白鳥橋地点は津波の影 響のある期間が久測となっているが，潮汐に伴う水位変 化を計算值が再現できていることを確認した．飯田橋地 点と日本橋水門地点は計算期間を通じて水位が観測でき ており, 最高水位についてみると飯田橋地点では観測值 がA.P.+2.43mに対して計算值はA.P.+2.59mであり観測值 と計算值の差は0.16mである. 日本橋水門地点では観測 值がA.P.+2.77mに対して計算值はA.P.+2.64mであり，そ の差は0.13mである. 亀島川の水門が閉鎖している条件

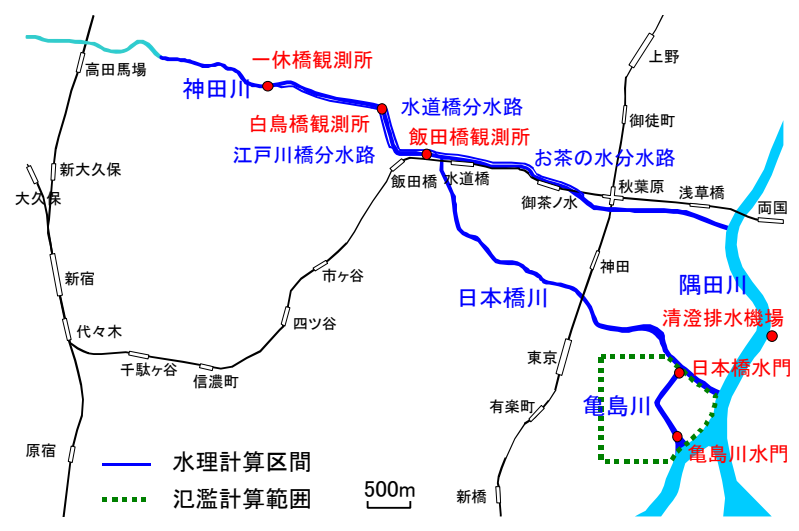

図-1 検討対象範囲
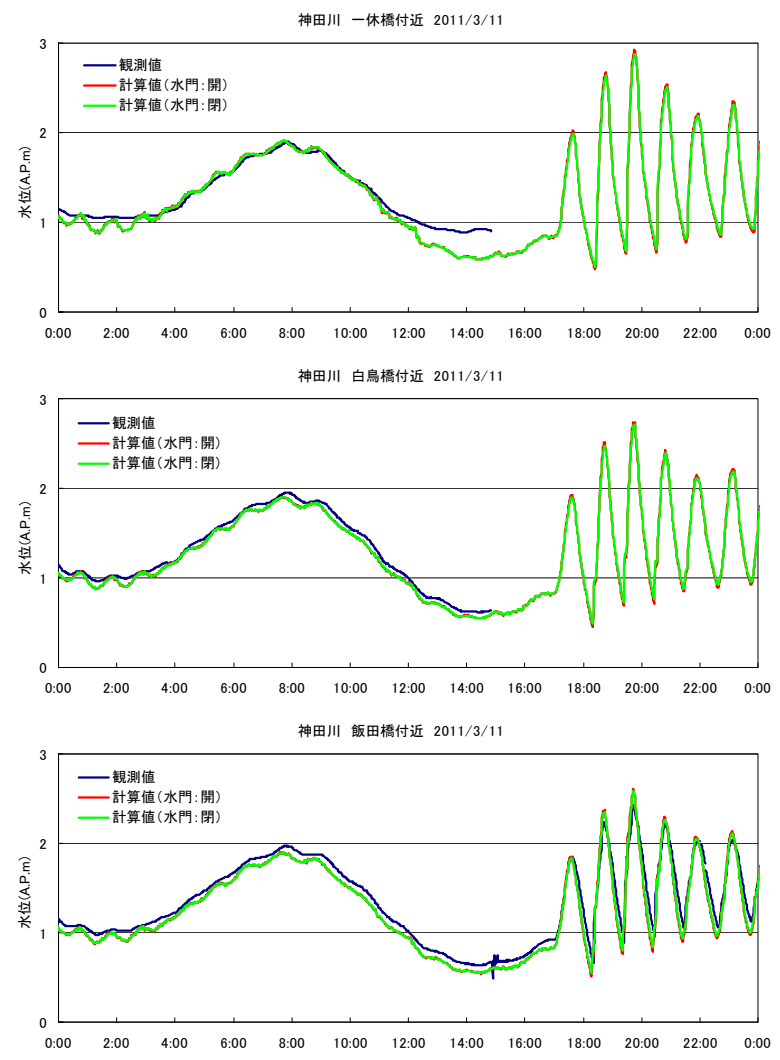

日本橋川 日本橋水門付近 $2011 / 3 / 11$
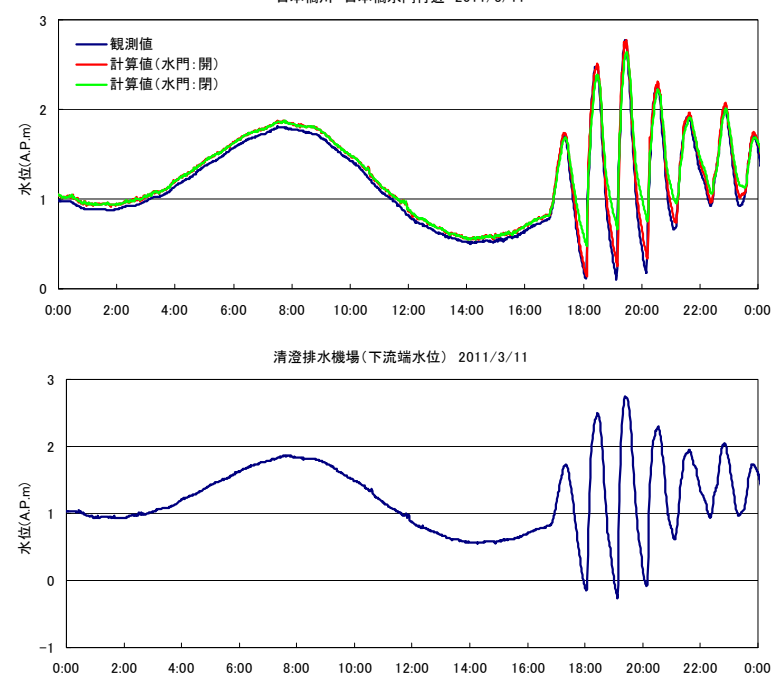

図-2 再現計算結果 
で3月11日24時間について計算值と観測值の差をみる と飯田橋地点では平均が-0.08m，標準偏差は $0.16 \mathrm{~m}$ ，日 本橋水門地点では平均が $0.08 \mathrm{~m}$ ，標準偏差は $0.11 \mathrm{~m}$ であり， 2地点の再現性に大きな違いはない。また，計算期間を 通じて計算值は観測值と同様の変化をしており，本計算 において設定した条件で津波による河川水位の変化を再 現できるものと判断した.

\section{（2）下流端における水位偏差}

一次元不定流計算において下流端水位に設定した清澄 排水機場について，津波がない場合の水位（以下，津波 除外水位）を推定し，津波除外水位と観測水位の違いか ら本津波による水位偏差を把握する. 水位観測が行われ ている清澄排水機場地点では，実績データによる学習結 果をもとに予測を行うニューラルネットワークモデル

（以下，ANN）を用いることで，潮汐，気圧，風向風 速を考慮した水位を推定できる ${ }^{9)}$. 津波除外水位を図-3 に示すように入力層, 中間層, 出力層の3層からなる階 層型ネットワークのANNにより推定する. 入力データ は天文潮位，気圧，風向・風速であり，出力が河川水位 となる．各ユニットにおいて式(1)および式(2)による計 算を行う。

$$
y_{i}=\frac{1}{1+\exp \left(-x_{i}\right)} \quad \text { (1) } \quad x_{i}=\sum_{i=1}^{n} w_{i j} y_{i}+b_{i}
$$

ここに，yi：ユニットiの出力值， $x_{i}$ : 入力值， $w_{i j}$ : 結合 荷重, $b_{i}$ : ユニット $i$ のバイアス值.

2002年から2010年のデータを用いてバックプロパゲー ション法によりANNの学習を行い，学習後のANNに予 測時の天文潮位，気圧，風向・風速を入力し，その出力 を津波除外水位とした。

2011年3月10日から13日における隅田川清澄排水機場 の河川水位について，観測值とANNによって推定した 津波除外水位を図-4に示す。観測值の最大值は A.P.+2.75mであり19時23分に発生している. 津波除外水 位についてみると本地震発生前は観測值と概小一致して いるが，地震発生後しばらくすると観測值と大きな違い を生じる．観測值と津波除外水位の変化から16時47分に 津波が到達したものと判断した.

河川水位の観測值と津波除外水位の差が津波による水 位偏差であると考えられる. 図-5に清澄排水機場の水位 偏差を示す．水位偏差は3月11日が特に大きく，水位偏 差の最大值1.47mは19時23分に発生している．水位偏差 の最大值の発生時刻は観測水位の最大值と同時である. 水位偏差は津波到達以降，計算期間末までみられ本津波 による水位への影響は数日間に及んでいる.

\section{（3）津波の有無による河川の水位偏差}

津波がある場合とない場合の神田川，日本橋川の河川 水位を計算し，各河川の水位偏差を求める．津波がない 場合の計算は，16時47分以降を図-4に示した津波除外水
位としたものを下流端水位とし，その他の設定を図-2に 示した再現計算と同じ条件として行った。 また，亀島川 の水門は本地震時の状況と同様に閉鎖しているものとし た. 津波がある場合の計算は，図-2の再現計算の内，水 門閉鎖の条件で計算したものとした.

図-6に一休橋地点と日本橋水門について本津波の有無

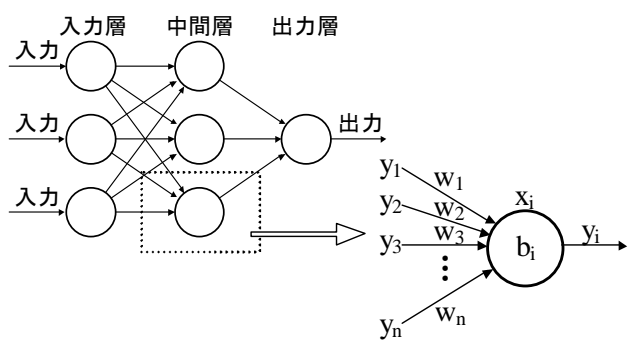

図-3 津波除外水位推定に用いたANN

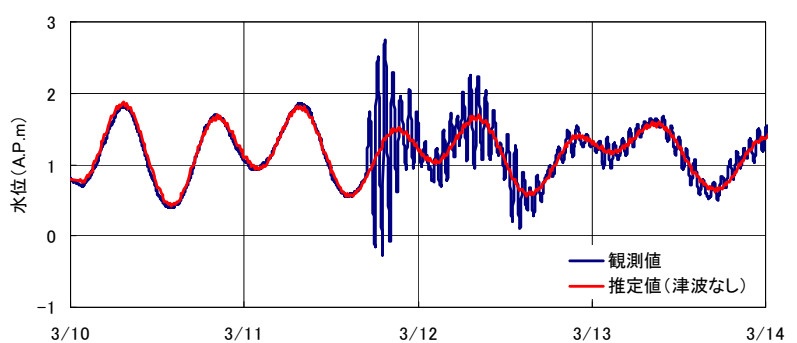

図-4 清澄排水機場の河川水位

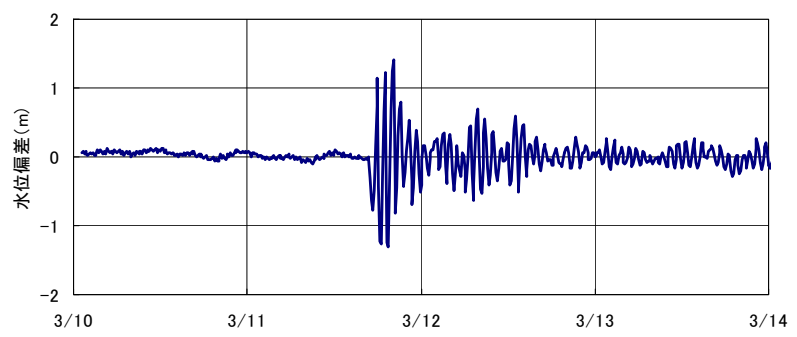

図-5 清澄排水機場の水位偏差
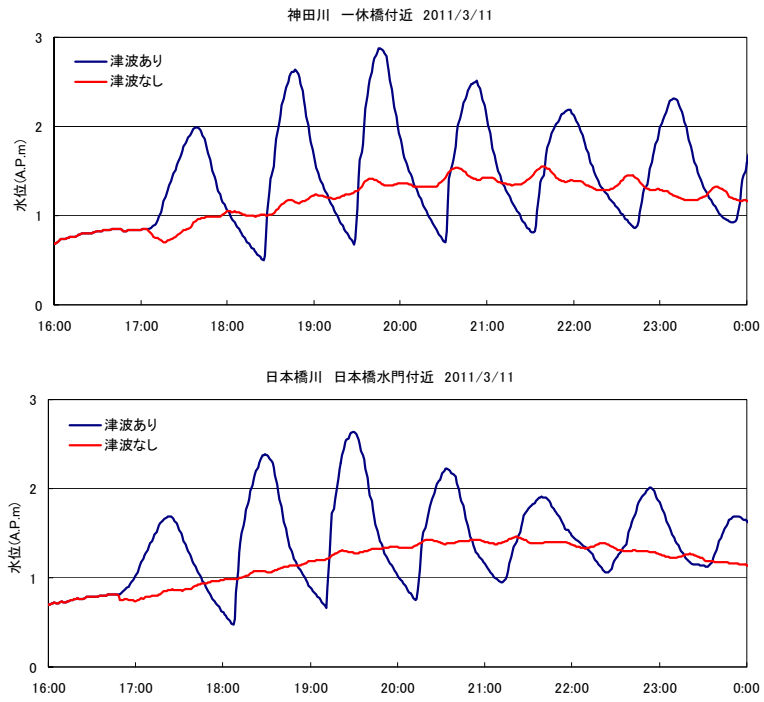

図-6 津波の有無による水位の変化 
による計算水位の変化を示す，また，本津波の有無によ る水位の差である水位偏差を図-7に示す．本津波による 水位偏差の最大值は一休橋地点が $1.51 \mathrm{~m}$, 白鳥橋地点が $1.34 \mathrm{~m}$, 飯田橋地点が $1.23 \mathrm{~m}$, 日本橋水門が $1.36 \mathrm{~m}$ となっ ており，4地点で最上流に位置する一休橋地点が最も大 きくなった. 水位偏差の最大值の発生時刻をみると下流 に位置寸る日本橋水門が19時30分, 一休橋地点が19時47 分であり，17分の違いがある．2地点間は8km離れてお り，水位偏差の最大值が発生した時刻をもとに津波の伝 播速度を計算すると $7.8 \mathrm{~m} / \mathrm{s}$ となる。

\section{4. 想定津波による影響}

\section{（1）河川水位}

想定津波に対する河川水位の変化を把握することを目 的として，まず，下流端における想定津波の波形を作成 する. ここでは南海トラフの巨大地震モデル検討会で示 された東京都区部の最大津波高3mを想定する．最大津 波高3mは満潮位T.P.0.93m ${ }^{10)}$ おび沈下量を含んでおり, 本検討の対象地域における沈下量は $0 \sim 0.1 \mathrm{~m}^{11)}$ とされて いる. 本検討では下流端水位波形を次の手順で作成した. 対象地域における沈下量を一律 $0.1 \mathrm{~m}$ し, 最大津波高 $3 \mathrm{~m}$ から満潮位0.93mおよび沈下量 $0.1 \mathrm{~m}$ を控除すると, 最 大水位偏差が1.97mとなる. 図-5に示した本津波による 水位偏差波形に対して最大水位偏差が $1.97 \mathrm{~m}$ となるよう に補正（1.34倍）し，この波形に朔望平均満潮位 A.P. $+2.077 \mathrm{~m}^{12)}$ を加えたものを図-8に示す下流端水位と した.

想定津波に対する計算は，沈下量0.1mを考慮して河川 断面全体の標高を0.1m下げたものとした. 図-8に示した 下流端水位を入力し，その他の設定は図-2の再現計算と 同様とした. また，亀島川の水門は閉鎖と開放の両方の 条件とした.

図-9に4地点における想定津波時の水位を示寸．水門 の閉鎖，開放による水位の違いをみると日本橋水門以外 の3地点ではほとんど違いがみられない，また，日本橋 水門においても最高水位については水門の閉鎖, 開放に よる違いは小さい. 水門開放時の4地点の最高水位は, 一休橋地点がA.P. $+4.59 \mathrm{~m}$, 白鳥橋地点がA.P. $+4.35 \mathrm{~m}$, 飯 田橋地点がA.P.+4.20m, 日本橋水門地点がA.P. $+4.15 \mathrm{~m}$ で ある.

神田川の3地点の最大水位は沈下量 $0.1 \mathrm{~m}$ 考慮した場 合においても堤防天端高より低くなっている．また，日 本橋水門地点の最高水位は沈下量を考慮した日本橋川の 堤防天端高より低いものの，現況で概ねA.P. $+4.0 \mathrm{~m} の$ 亀 島川の堤防天端高を上回っている. 亀島川全体の最高水 位についてみると日本橋水門の下流地点がA.P.+4.15m, 亀島川中間付近がA.P.+4.15m, 亀島川水門の上流地点が A.P.+4.09mとなっている.

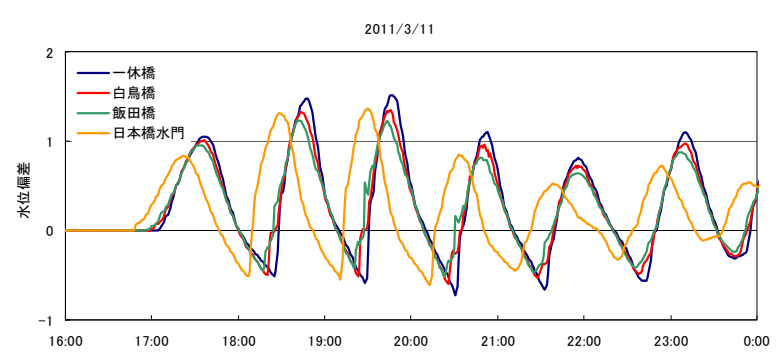

図-7 4地点の水位偏差

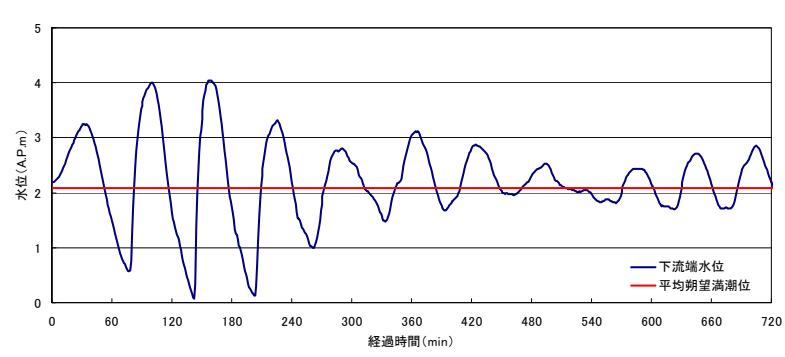

図-8 想定津波に対する下流端水位

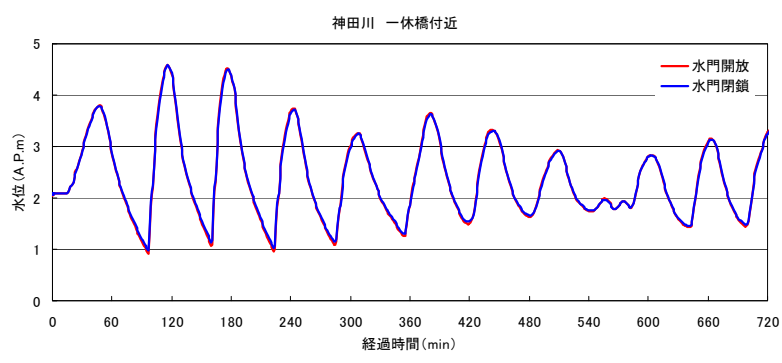

神田川 白鳥橋付近

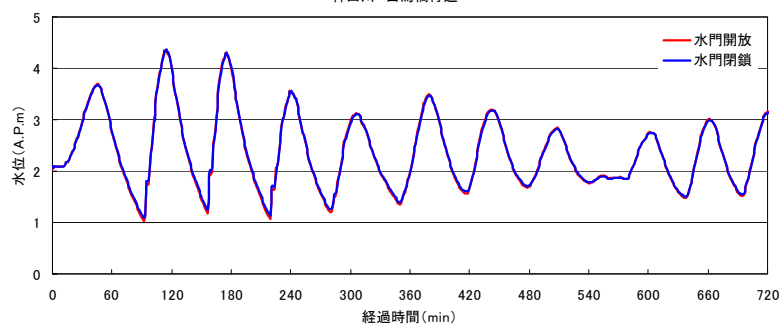

神田川 飯田橋付近

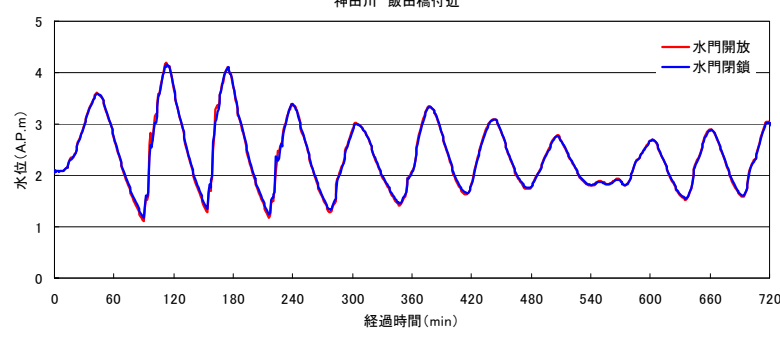

日本橋川日本楅水門付近

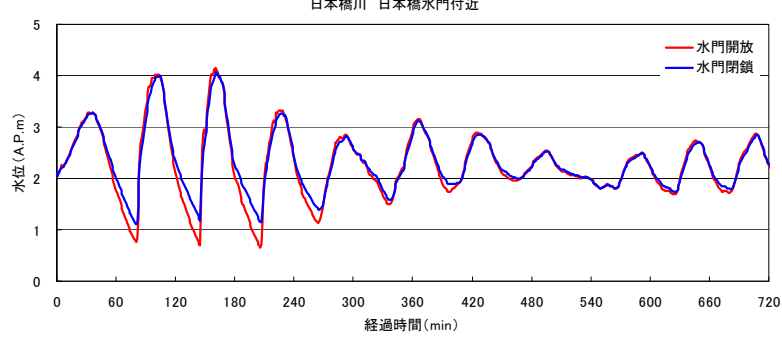

図-9 想定津波時の水位変化 
亀島川の2つの水門を閉鎖した場合，日本橋川や神田 川の最高水位は堤防天端高より低いので氾濫を生じない が，亀島川の水門が閉鎖できなかった場合には，亀島川 の周辺で汇濫が生じる. 本地震においては全国で水門閉 鎖に際して様々な支障があったことが報告されており1), 巨大地震に伴う津波に対して亀島川の水門の機能維持は 極めて重要である.

水門閉鎖時の日本橋水門と一休橋地点の3つ目のピー ク水位の発生時間をみると, 日本橋水門は161分経過時 点，一休橋地点は177分経過時点であり，16分の違いが ある. ピーク水位の発生時間をもとに津波の伝播速度を 計算すると $8.3 \mathrm{~m} / \mathrm{s}$ となり, 本地震に対する伝播速度より 速くなっている.

\section{（2）都心部の汇濫状況}

亀島川溢水時の汇濫状況をi-RIC2.0.0（iRICプロジェク ト）のソルバーNays2D Floodを用いて計算した. 地盤高 は国土地理院の基盤地図情報（数值標高モデル） $5 \mathrm{~m}$ メッシュ（標高）を用い，堤防および河床に位置する地 盤高にはそれぞれの高さを入力した．沈下量0.1mを考慮 するため全ての地盤高を $0.1 \mathrm{~m}$ 低く補正した。汇濫計算に 際しては10m格子データを作成し，各格子の粗度係数は 式(3)を用いることにより建物占有率を考慮した ${ }^{13)}$.

$$
n^{2}=n_{0}{ }^{2}+0.02 \times \frac{\theta}{100-\theta} \times h^{\frac{4}{3}}
$$

ここに, $n$ : 粗度係数, $n_{0}$ : 底面粗度係数, $\theta$ : 建物 占有率, $h:$ 水深.

対象範囲では建物以外の多くを道路が占めることから $n_{0}=0.047$ とし, 使用ソフトが浸水深に応じて粗度係数を 変更することができないため，浸水域の平均的な水深を 試算によって確認し $h=0.3 \mathrm{~m}$ として粗度係数を計算した.

初期水位を $0.00 \mathrm{~m}$ して，図-8に示した想定津波水位 を亀島川の上流側および下流側に与え, 津波到達時から 300分経過後まで計算を行った。 なお，汇濫計算ではポ ンプ等の雨水排水施設は考慮していない，また，計算を 行った地域では様々な地下空間利用が行われているが, 計算において地下空間への浸水は考慮していない.

図-10に津波到達100分後, 110分後, 120分後の浸水深 を100m格子と共に示した.（a)に示した100分後では亀 島川から約300m離れた位置までが浸水範囲となり, 約 100m離れた位置に大きな浸水深がみられる. また，地 下に位置する東京メトロの茅場町駅と八丁堀駅, JR京葉 線八丁堀駅が浸水範囲に含まれている. (b) の 110 分後で は (a) と比べて $100 m$ 程度浸水範囲が広がり西端は周辺地 盤より低い位置にある首都高都心環状線に到達寸る。ま た，大きな浸水深が亀島川から約300m離れた位置にみ られる. (c) の120分後は (b) と比べて浸水範囲は大きく は変わらないが首都高都心環状線の浸水深が大きくなっ ている. （a） 100 分後の浸水深

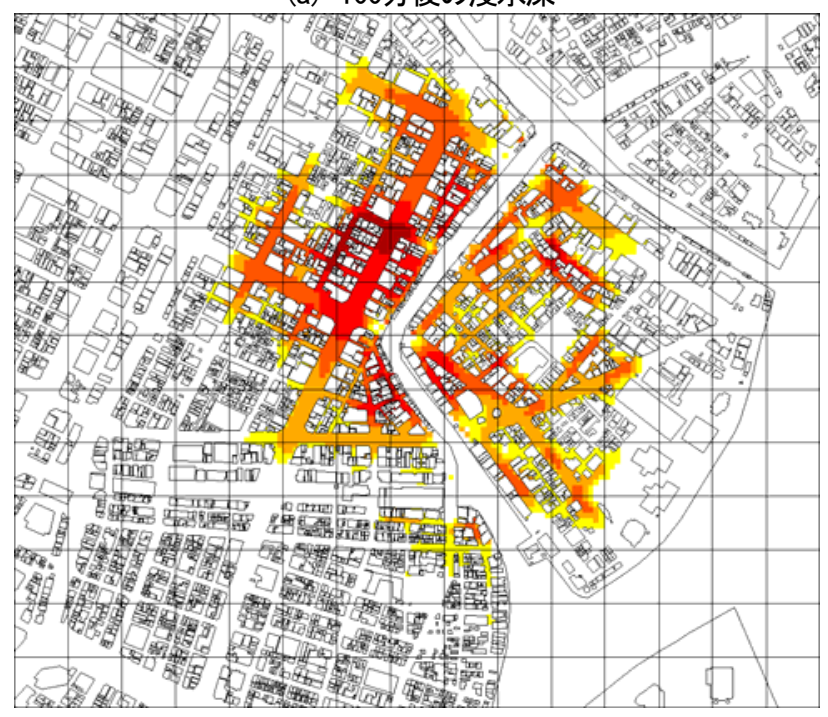

(b) 110分後の浸水深

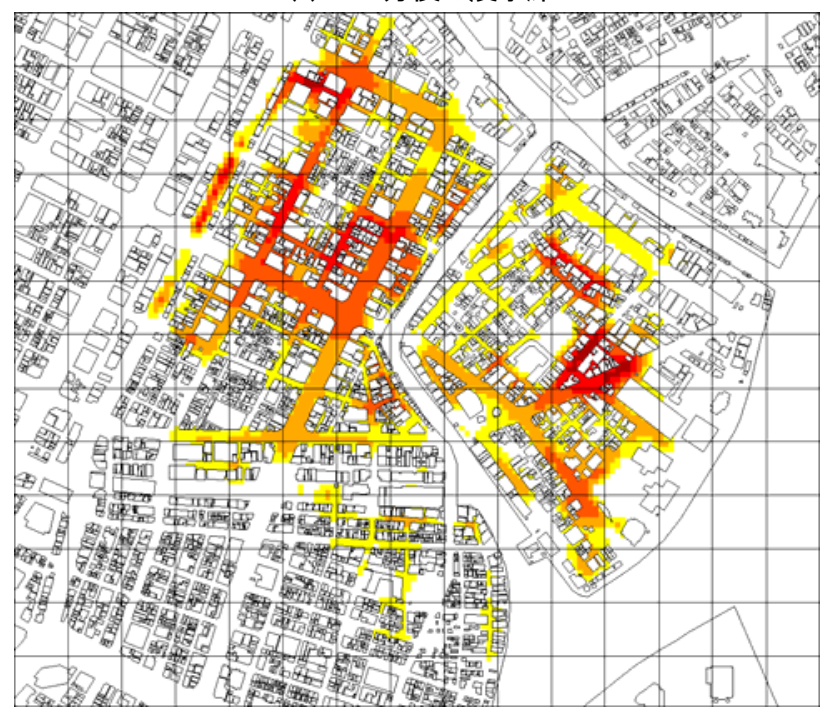

(c) 120分後の浸水深

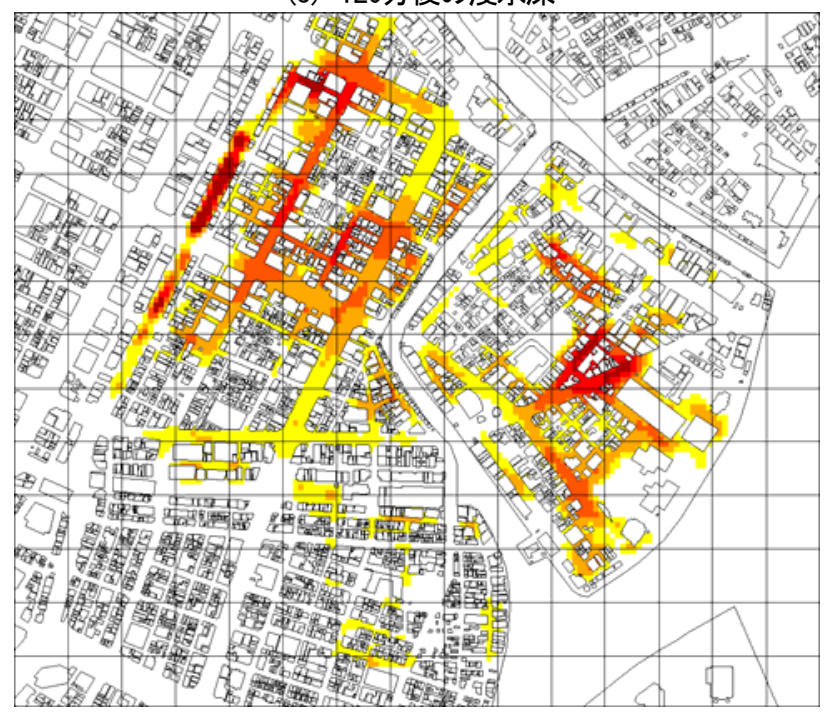

凡例

$0.05 \sim 0.2 \mathrm{~m}$

$0.2 \sim 0.4 \mathrm{~m}$

$0.4 \sim 0.6 \mathrm{~m}$

$0.6 \sim 0.8 \mathrm{~m}$

$0.8 \mathrm{~m} \sim$

\section{図-10 津波汇濫予測（浸水深）}




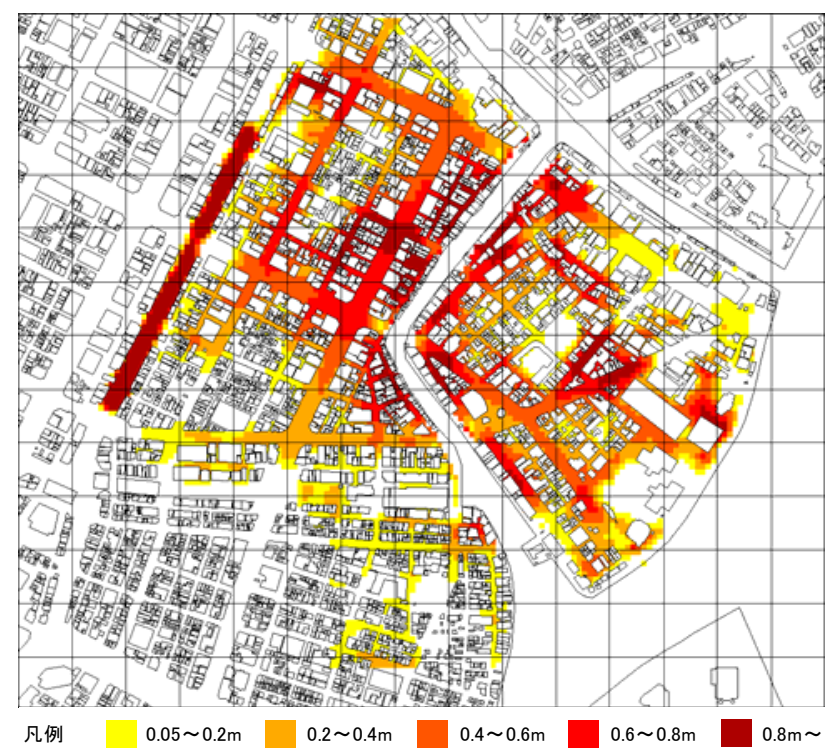

図-11 津波氾濫予測（最大浸水深）

図-11に津波到達180分後の最大浸水深を示した. この 時点の最大浸水深は首都高都心環状線における3.7mであ り，浸水深 $0.05 \mathrm{~m}$ 以上の範囲は $0.64 \mathrm{~km}^{2}$ となっている．浸 水範囲についてみると図-10の (c) と比べて亀島川の東側 は広がっているが亀島川の西側は大きくは変わらない． 津波到達300分後の浸水範囲は $0.65 \mathrm{~km}^{2}$ であり 180 分後と ほとんど変わらないものの首都高都心環状線における最 大浸水深は4.8mと大きくなる.

浸水範囲ではビルの地下等についても様々な利用がさ れており，こうした場所一の浸水によって大きな被害が 生じる可能性がある.

\section{5. まとめ}

東京都心部を流れる神田川，日本橋川，亀島川を対象 に，今後発生が想定される巨大地震に伴う津波に対する 河川水位の変化を計算し, 水位が堤防を越える区間の周 辺を対象に汇濫計算を行った。 これらの計算をもとに考 察した結果, 以下の知見を得た.

津波による中小河川の水位変化を一次元不定流計算に より良好に再現することが可能である．本解析では多く の河川や分水路加構成される比較的複雑な区間を対象 としており，他の中小河川においても同様の方法で十分 な再現性を得ることができると考えられる．また，感潮 域の洪水計算では流入量把握の問題から水理計算に用い る粗度係数の妥当性を検証することは難しいが，津波に 対する再現計算では平水時の流量を考慮すればよいので, 適切な粗度係数の設定が容易である. 感潮域の中小河川 においては粗度係数の検証を目的として津波に対寸る再 現計算を行うことは有用だと思われる.

想定津波に対して亀島川の2つの水門を閉鎖した場合， 氾濫は生じない，津波対策において水門機能の維持管理
は極めて重要であり, 巨大地震発生時に想定される様々 な障害に対して機能が失われない対策を講じることが望 まれる。

想定津波に対して亀岛川の水門を閉鎖できなかった場 合, 亀島川周辺で汇濫が生じる．浸水範囲では地下空間 利用が多く行われていることから，地下空間においては 津波による浸水も考慮することが望まれる.

今回検討を行った神田川, 日本橋川, 亀島川以外の中 小河川においても津波汇濫が生じる可能性がある．特に 地下空間利用が行われている都市部においては地震に対 寸る安全性や防災対策を検討する際に，周辺を流れる中 小河川について地震津波の影響を十分に考慮することが 必要だと考える.

\section{参考文献}

1) 東北地方太平洋沖地震を踏まえた河口堰・水門等技術検討 委員会 : 東日本大震災を踏まえた堰・水門等の設計、操作の あり方について, pp.6-14, 2011.

2) 国土交通省国土技術政策総合研究所, 独立行政法人土木研 究所 : 平成23年（2011年）東北地方太平洋沖地震土木施設災 害調查速報, 2011.

3) 国土交通省関東地方整備局荒川下流河川事務所 : 記者発表 資料 平成23年（2011年）東北地方太平洋沖地震における荒 川下流管内の被災状況について(とりまとめ), 2011.

4) 東京都防災会議 : 首都直下地震等による東京の被害想定報 告書, pp.2-42〜2-74, 2012.

5) 南海トラフの巨大地震による震度分布・津波高について （第一次報告），巻末資料， 2012.

6) 南海トラフの巨大地震による津波高・浸水域等（第二次報 告）及び 被害想定（第一次報告）について，資料 $1-2$ 都 府県別市町村別最大津波高一覧表＜満潮位＞， 2012.

7) 東京都土木技術センター : 神田川他流量観測等調查委託報 告書, 2008.

8) 増田信也, 高崎忠勝 : 神田川流域における粗度係数の実態, 平成16年東京都土木技術研究所年報, pp.171-186, 2004.

9) 高崎忠勝, 河村明, 天口英雄 : ニューラルネットワークに よる都市中小河川感潮域の水位推定, 水工学論文集, 第55巻, pp.S1603-S1608, 2011.

10）南海トラフの巨大地震モデル検討会（第二次報告）津波断 層モデル編一津波断層モデルと津波高・浸水域等について一 計算結果集（津波高等）, pp.97, 2012.

11）南海トラフの巨大地震モデル検討会（第二次報告）強震断 層モデル編（別添資料）一液状化可能性、沈下量について一, pp. 25, 2012.

12) 東京都港湾局 : 平成24年東京港24時間潮位表, 2012.

13) 建設省土木研究所 : 氾濫シミュレーション・マニュアル (案), pp.12-14, 1996. 